\title{
Application of New Thermodynamic Data to Grossular Phase Relations*
}

\author{
Dexter Perkins, III ${ }^{1 *}$, Eric J. Essene ${ }^{1}$, Edgar F. Westrum, $\mathrm{Jr}^{2}$, \\ and Victor J. Wall ${ }^{3}$ \\ ${ }^{1}$ University of Michigan, Department of Geology and Mineralogy, Ann Arbor, Michigan 48109, USA \\ ${ }^{2}$ University of Michigan, Department of Chemistry, Ann Arbor, Michigan 48109, USA \\ ${ }^{3}$ Monash University, Department of Geology, Clayton, Victoria, Australia
}

\begin{abstract}
Recent low temperature, adiabatic calorimetric heat capacity measurements for grossular have been combined with DSC measurements to give entropies up to $1000 \mathrm{~K}$. In conjunction with enthalpy of solution values for grossular, these data have yielded $\Delta H_{\mathrm{f}}^{\mathrm{O}}(298.15 \mathrm{~K})$ and $\Delta G_{\mathrm{f}}^{\mathrm{O}}(298.15 \mathrm{~K})$ values of $-1583.2 \pm 3.5$ and $-1496.74 \pm 3.7 \mathrm{kcal} \mathrm{mol}^{-1}$ respectively. For 15 reactions in the $\mathrm{CaO}-\mathrm{Al}_{2} \mathrm{O}_{3}-\mathrm{SiO}_{2}-\mathrm{H}_{2} \mathrm{O}$ system, thermodynamically calculated $P-T$ curves have been compared with experimental reversals and have shown good agreement in most cases. Calculations indicate that gehlenite is probably totally disordered. Estimates of zoisite and lawsonite entropies are consistent with the phase equilibrium and grossular data, but estimates of the entropies of pyrope and andradite show large discrepancies when compared with experimental reversals.
\end{abstract}

\section{Introduction}

The $\mathrm{Ca}-\mathrm{Al}$ garnet grossular $\left(\mathrm{Ca}_{3} \mathrm{Al}_{2} \mathrm{Si}_{3} \mathrm{O}_{12}\right)$, one of the most common natural garnets, is characteristic of both contact and regionally metamorphosed rocks. Knowledge of its stability compared to that of other calcium aluminium silicates can yield valuable information about the pressure, temperature, and fluid composition under which these rocks equilibrated. Some experimental studies have been conducted on reactions involving grossular, but no accurate thermodynamic data were available until recently on grossular itself.

Reliable thermodynamic data for the phases involved permits evaluation of experimental work and allows its extrapolation to different pressures and temperatures. Hays (1967) estimated grossular entropies at high pressures and temperatures using the slopes of experimentally determined reactions. However, large uncertainties were occasioned by extrapolation to metamorphic pressures and temperatures. Westrum et al. (1977) have carefully measured the heat capacity of grossular collected at Thetford, Quebec, from $5 \mathrm{~K}$ to $600 \mathrm{~K}$ using intermittent heating, adiabatic, calorimetric techniques. We have now combined these

* Contribution no. 600 from the Mineralogical Laboratory, The Department of Geology and Mineralogy, The University of Michigan, Ann Arbor, Michigan 48109, USA 
Table 1. Heat capacity and entropy and enthalpy of grossular

\begin{tabular}{llll}
\hline $\mathrm{T}$ & $\begin{array}{l}\mathrm{C}_{\mathrm{p}} \\
\mathrm{K}\end{array}$ & $\begin{array}{l}\mathrm{S}^{0}-\mathrm{S}_{\mathrm{o}}^{0} \\
\left(\mathrm{cal} \mathrm{K}^{-1} \mathrm{~mol}^{-1}\right)\end{array}$ & $\begin{array}{l}\mathrm{H}_{\mathrm{T}}-\mathrm{H}_{\mathrm{o}}^{0} \\
\left(\mathrm{cal} \mathrm{K}^{-1} \mathrm{~mol}^{-1}\right)\end{array}$ \\
\hline 100 & 20.33 & 8.16 & .61 \\
150 & 39.67 & 20.12 & 2.12 \\
200 & 56.12 & 33.87 & 4.53 \\
250 & 69.08 & 47.85 & 7.68 \\
298.15 & 78.69 & 60.87 & 11.25 \\
300 & 79.06 & 61.37 & 11.39 \\
400 & 92.73 & 86.15 & 20.04 \\
450 & 97.49 & 97.36 & 24.80 \\
500 & 101.32 & 107.84 & 29.77 \\
550 & 104.32 & 117.64 & 34.92 \\
600 & 107.06 & 126.83 & 40.20 \\
650 & 109.1 & 135.4 & 45.61 \\
700 & 110.9 & 143.6 & 51.08 \\
750 & 112.4 & 151.3 & 56.66 \\
800 & 113.7 & 158.5 & 62.30 \\
850 & 114.9 & 165.5 & 68.02 \\
900 & 115.9 & 172.1 & 73.72 \\
950 & 116.8 & 178.4 & 79.59 \\
1000 & 117.6 & 184.3 & 85.44 \\
\hline
\end{tabular}

results with differential scanning calorimeter (DSC) measurements to produce entropy and enthalpy values up to $1000 \mathrm{~K}$. High temperature heat capacities were measured on a Perkin-Elmer DSC-2 in R.A. Robie's laboratory at the United States Geological Survey in Reston, Virginia. Eight overlapping scans, of approximately $100^{\circ} \mathrm{C}$ intervals, at a heating rate of $10{ }^{\circ} \mathrm{C} / \mathrm{min}$, compared the heat capacity of a $30.86 \mathrm{mg}$ grossular sample to that of a $30.66 \mathrm{mg}$ corundum standard. Molal heat capacities were calculated by the computer program DSC-7c (Krupka, 1976) which utilized the heat capacity of corundum from Ditmars and Douglas (1971). The DSC data joined smoothly with the adiabatic calorimetric results at $600^{\circ} \mathrm{C}$ and all overlapping DSC runs agreed to within $0.5 \%$. The accuracy was estimated to be $1 \%$ (Robie, personal communication). Complete thermodynamic functions were then tabulated by our computer program FITAB. Our values, as listed in Table 1, compare closely with those obtained by Robie and Hemingway on a similar Thetford garnet (personal communication). Comparison of our values with those estimated by Hays (1967) shows a difference in entropy of 2 to $4 \mathrm{cal} \mathrm{K}^{-1} \mathrm{~mol}^{-1}$ at low temperature. The discrepancy is probably explained by errors in Hays' extrapolations from experiments at $600-1300^{\circ} \mathrm{C}$ and $10-20 \mathrm{kbar}$.

\section{Enthalpies and Gibbs Energies of Formation}

Newton, Charlu and Kleppa (1975) measured the enthalpy of solution of grossular, $\mathrm{CaO}, \mathrm{Al}_{2} \mathrm{O}_{3}$, and $\mathrm{SiO}_{2}$, in lead-borate solution at $970^{\circ} \mathrm{K}$, which yielded a $\Delta H_{\mathrm{f}}^{\mathrm{o}}\left(970 \mathrm{~K}\right.$, from oxides) for grossular of $-76.36 \pm 1.01 \mathrm{kcal} \mathrm{mol}^{-1}$. Combining this value with $\Delta H_{\mathrm{f}}^{0}$ values for oxides (Robie and Waldbaum, 1968) and our 
entropy values yields $\Delta G_{\mathrm{f}}^{0}$ values for grossularite of $-1299.97 \pm 3.41 \mathrm{kcal} \mathrm{mol}^{-1}$ at $970^{\circ} \mathrm{K}$, and $-1496.73 \pm 3.41 \mathrm{kcal} \mathrm{mol}^{-1}$ at $298^{\circ} \mathrm{K}$. Table 2 lists our values of enthalpy and Gibbs energy of formation at $298.15 \mathrm{~K}$ along with those of Hays (1967), as cited in Robie and Waldbaum (1968), and Thompson (1974).

Table 2. Standard enthalpies and gibbs energies of formation from elements of grossular at $298.15 \mathrm{~K}$

\begin{tabular}{lcl}
\hline & $\begin{array}{l}\Delta H_{\mathrm{f}}^{0} \\
\left(\mathrm{kcal} \mathrm{mol}^{-1}\right)\end{array}$ & $\begin{array}{l}\Delta G_{\mathrm{f}}^{0} \\
\left(\mathrm{kcal} \mathrm{mol}^{-1}\right)\end{array}$ \\
\hline$-H a y s(1966)$ & $-1588.393 \pm 1.830$ & $-1500.986 \pm 1.880$ \\
Thompson $(1974)$ & - & $-1509 \pm 2.5$ \\
This study & $-1583.2 \pm 3.5$ & $-1496.73 \pm 3.41$ \\
\hline
\end{tabular}

The differences in these $\Delta H_{\mathrm{f}}^{0}$ and $\Delta G_{\mathrm{f}}^{0}$ may seem insignificant when compared with the total values. They are extremely important, however, when calculating equilibria in solid-solid reactions for which $\Delta S$ and $\Delta V$ are small. For example, an increase in $\Delta G_{\mathrm{f}}^{0}$ (grossular) of $4 \mathrm{kcal} \mathrm{mol}^{-1}$ shifts the reaction $2 \mathrm{Gr}=\mathrm{An}+\mathrm{Ge}+3 \mathrm{Wo}$ by up to $+2 \mathrm{kbars}$ or $-100 \mathrm{~K}$. The discrepancy between our $A G_{\mathrm{f}}^{0}$ (grossular) and that of Thompson is particularly important since it suggests that there may be errors in some of Thompson's other "consistent" values.

\section{Reaction Equilibria}

Grossular is involved in a large number of metamorphic reactions. For the purposes of this investigation, then of the best known subsolidus reactions were chosen. An additional five reactions were studied in order to check the accuracy of our entropy estimates for zoisite and lawsonite. Thermodynamic calculations were made using the computer program EQUILI of Wall and Essene. Given an initial $\Delta G_{\mathrm{r}}\left(P_{1}, T_{1}\right)$ and $X\left(\mathrm{H}_{2} \mathrm{O}\right), \Delta G_{\mathrm{r}}\left(P_{2}, T_{2}\right)$ can be calculated as follows:

$$
\Delta G_{\mathrm{r}}\left(P_{2}, T_{2}\right)=\Delta G_{\mathrm{r}}\left(P_{1}, T_{1}\right)+\int_{P_{1}}^{P_{2}} \Delta V_{\mathrm{r}} d P-\int_{r_{1}}^{T_{2}} \Delta S_{\mathrm{r}} d T .
$$

In order to evaluate $\Delta V_{\mathrm{r}}(P, T)$ and $\Delta S_{\mathrm{r}}(P, T)$ thermal expansion $(\alpha)$ and compressibility $(\beta)$ were used to calculate $V(P, T)$ and $S(P, T)$ for each phase as follows:

$$
\begin{aligned}
& V(P, T)=V^{0}(298.15)+\int_{298.15}^{T} \alpha V d P-\int_{1 \mathrm{~atm}}^{P} \beta V d V . \\
& S(P, T)=S^{0}(T)-\int_{1 \mathrm{~atm}}^{P} \alpha V d P .
\end{aligned}
$$

It was assumed that $\alpha(P, T)=\alpha^{0}(T)$ and $\beta(P, T)=\beta^{\circ}(298.15)$. All $V^{0}$ values were taken from Robie, Bethke and Beardsley (1967). $\alpha$ and $\beta$ were taken from Skinner (in Clark, 1966) or estimated on the basis of data on minerals of similar crystal 
structure. $S^{0}(T)$ values were taken directly from Robie and Waldbaum (1968) for all phases except grossular, zoisite, lawsonite and gehlenite. The grossular values used were our own; the zoisite and lawsonite values were estimated by schemes that will be described below, and the gehlenite values were calculated by adding $2 \mathrm{R} \ln (2)$ to the values in Robie and Waldbaum (cf. Waldbaum, 1973) to correct for disorder of $\mathrm{Al}$ and $\mathrm{Si}$ as noted by Smith (1953), and Louisnathan (1971).

\section{(1)}

$$
\begin{aligned}
& \text { 4zoisite }+ \text { quartz }=5 \text { anorthite }+ \text { grossular }+2 \text { water } \\
& 4 \mathrm{Ca}_{2} \mathrm{Al}_{3} \mathrm{Si}_{3} \mathrm{O}_{12}(\mathrm{OH})+\mathrm{SiO}_{2}=5 \mathrm{CaAl}_{2} \mathrm{Si}_{2} \mathrm{O}_{8}+\mathrm{Ca}_{3} \mathrm{Al}_{2} \mathrm{Si}_{3} \mathrm{O}_{12}+2 \mathrm{H}_{2} \mathrm{O}
\end{aligned}
$$

This reaction has been reversed by Newton (1966) and Boettcher (1970) and has been the subject of some earlier studies by Nitsch and Winkler (1962) and Merrin (1962). The reversals of Newton and Boettcher are plotted on Figure 1. In order to make thermodynamic calculations on this reaction it was necessary to estimate the entropy of zoisite. Heat capacities have been measured for zoisite by Kiseleva, Topor, and Andreyenko (1974), but their derived entropies do not yield the experimentally determined slopes of the equilibria (1) and (2), when combined with our entropy data for grossularite, and the available data for the other phases (Robie and Waldbaum, 1968). This is most likely due to error in their estimation of $S^{0}$ (zoisite, $298.15 \mathrm{~K}$ ); they made no measurements below $300 \mathrm{~K}$. Several different schemes for estimating entropy were attempted and applied to the two zoisite reactions considered in this paper. Results most consistent with experiments were obtained by approximating:

$$
\mathrm{S}(\text { zoisite })=\left\{1 / 2 \mathrm{~S}_{\mathrm{ms}}+2 \mathrm{~S}_{\mathrm{ky}}+4 \mathrm{~S}_{\mathrm{di}}-4 \mathrm{~S}_{\mathrm{en}}-\mathrm{S}_{\mathrm{mic}}\right\}
$$

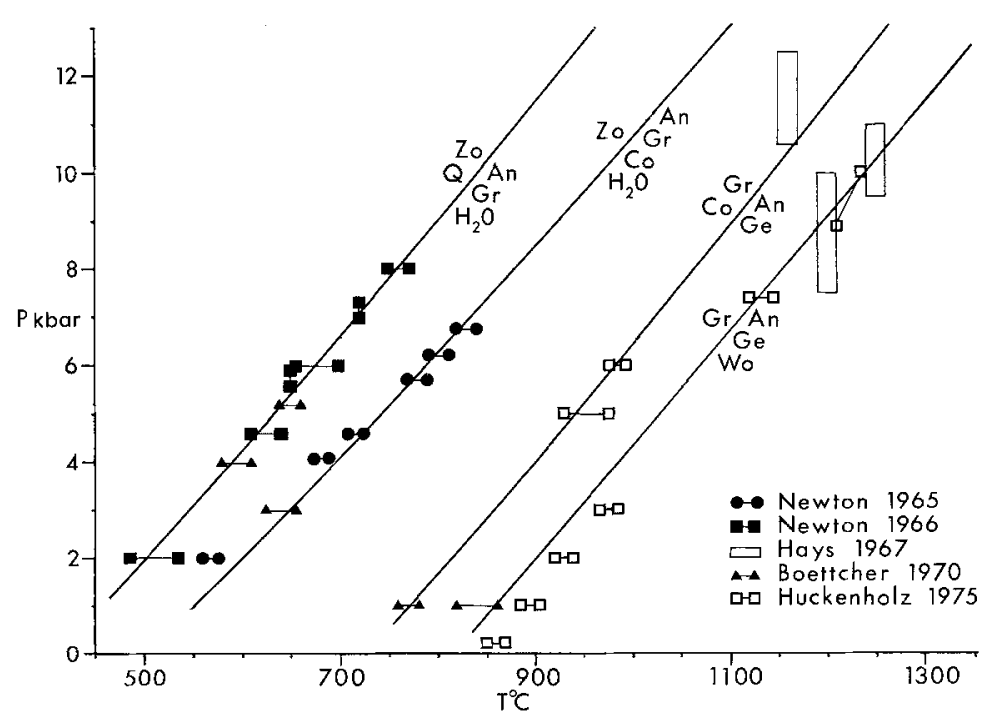

Fig. 1. Pressure-temperature diagram comparing the results of the thermodynamic extrapolations of this study with experimental results obtained by Newton (1965), Newton (1966), Hays (1967), Boettcher (1970), and Huckenholz et al. (1975) 
where $\mathrm{ms}=$ muscovite, $\mathrm{ky}=\mathrm{kyanite}, \mathrm{di}=$ diopside, $\mathrm{en}=$ enstatite, and $\mathrm{mic}=$ microcline. The values obtained by this approximation are given in Table 3 .

The estimated entropy values were used to extrapolate a curve from Newton's $720^{\circ} \mathrm{C}$ reversal. It passed through all reversals except one, missing Newton's reversal at $650^{\circ} \mathrm{C}$ by $10^{\circ} \mathrm{C}$ (Figure 1 ).

(2) 6 zoisite $=6$ anorthite +2 grossular + corundum +3 water

$$
6 \mathrm{Ca}_{2} \mathrm{Al}_{3} \mathrm{Si}_{3} \mathrm{O}_{12}(\mathrm{OH})=6 \mathrm{CaAl}_{2} \mathrm{Si}_{2} \mathrm{O}_{8}+2 \mathrm{Ca}_{3} \mathrm{Al}_{2} \mathrm{Si}_{3} \mathrm{O}_{12}+\mathrm{Al}_{2} \mathrm{O}_{3}+3 \mathrm{H}_{2} \mathrm{O}
$$

The breakdown reaction of zoisite to anorthite, grossular, corundum and water (reaction 2) has been reversed Newton (1965) and Boettcher (1970). An extrapolated curve consistent with our grossular entropy and our estimated zoisite entropy passes through all reversals except Newton's at 4 kbar. The small disagreement is easily within the range of experimental uncertainty.

Table 3. Estimated entropy of zoisite

\begin{tabular}{llll}
\hline$\frac{\mathrm{T}}{\mathrm{K}}$ & $\begin{array}{l}\mathrm{S}^{0} \\
\left(\mathrm{cal} \mathrm{mol}^{-1} \mathrm{~K}^{-1}\right)\end{array}$ & $\frac{\mathrm{T}}{\mathrm{K}}$ & $\begin{array}{l}\mathrm{S}^{0} \\
\left(\mathrm{cal} \mathrm{mol} \mathrm{mol}^{-1} \mathrm{~K}^{-1}\right)\end{array}$ \\
\hline 298.15 & 67.6 & 700 & 156.3 \\
300 & 68.2 & 750 & 164.8 \\
400 & 93.6 & 800 & 172.9 \\
450 & 105.6 & 850 & 180.6 \\
500 & 117.0 & 900 & 187.9 \\
550 & 127.8 & 950 & 194.9 \\
600 & 137.8 & 1000 & 201.6 \\
650 & 147.4 & 1050 & 208.1 \\
& & 1100 & 214.3 \\
\hline
\end{tabular}

(3)

$$
\text { grossular }+ \text { corundum }=\text { anorthite }+ \text { gehlenite }
$$

$$
\mathrm{Ca}_{3} \mathrm{Al}_{2} \mathrm{Si}_{3} \mathrm{O}_{12}+\mathrm{Al}_{2} \mathrm{O}_{3}=\mathrm{CaAl}_{2} \mathrm{Si}_{2} \mathrm{O}_{8}+\mathrm{Ca}_{2} \mathrm{Al}_{2} \mathrm{SiO}_{7}
$$

Reaction 3 has been reversed by Boettcher $(1970)$ at $1 \mathrm{kbar}$ and $760^{\circ} \mathrm{C}$ to $780^{\circ} \mathrm{C}$ and at higher pressures by Huckenholz et al. (1975). Hays (1967) has located an invariant point at approximately $11.6 \mathrm{kbar}$ and $1160^{\circ} \mathrm{C}$ through which it must pass. Extrapolation from Boettcher's reversal, assuming disordered gehlenite, passes through Hay's location for the invariant point, and is consistent with all reversals of Huckenholz et al. (Fig. 1).

(4) 2 grossular $=$ anorthite + gehlenite +3 wollastonite

$$
2 \mathrm{Ca}_{3} \mathrm{Al}_{2} \mathrm{Si}_{3} \mathrm{O}_{12}=\mathrm{CaAl}_{2} \mathrm{Si}_{2} \mathrm{O}_{8}+\mathrm{Ca}_{2} \mathrm{Al}_{2} \mathrm{SiO}_{7}+3 \mathrm{CaSiO}_{3}
$$

Reaction 4 has been reversed by Hays (1967), Boettcher (1970) and Huckenholz et al. (1975). The reversals of Huckenholz et al. are in disagreement with Boettcher's 1 kbar brackets but are consistent with Hays' reversals at higher pressures (Fig. 1). Extrapolation from Boettcher's 1 kbar reversal yields a curve (Fig. 1) that is consistent with the other two studies at high pressure. The calculated slope of 


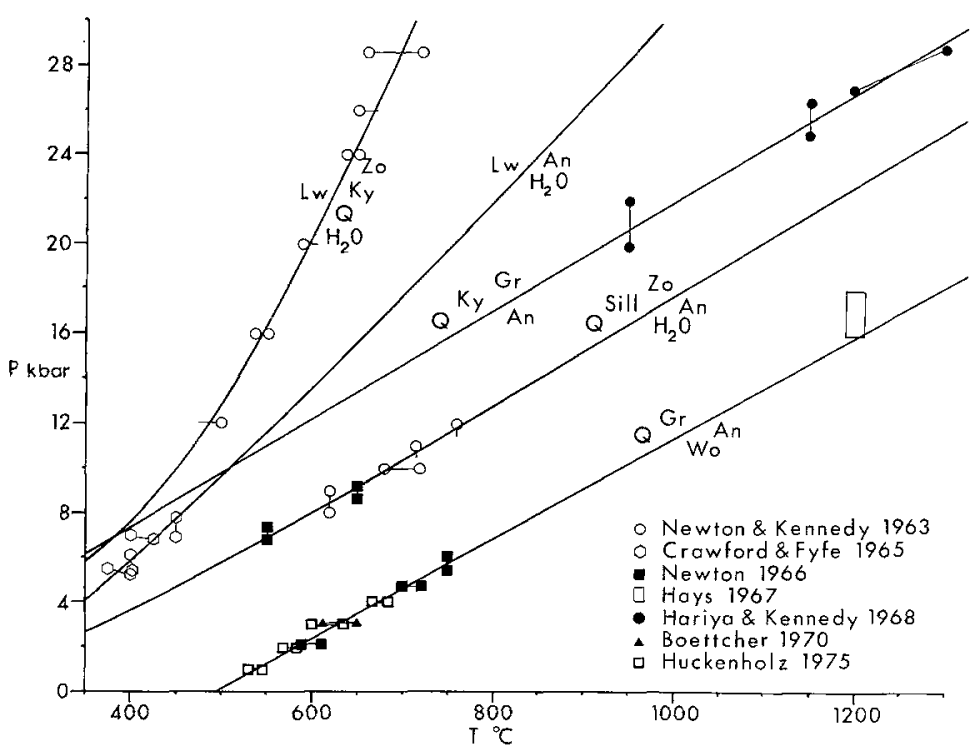

Fig. 2. Pressure-temperature diagram comparing the thermodynamic extrapolations of this study with experimental results of Newton and Kennedy (1963), Crawford and Fyfe (1965), Newton (1966), Hays (1967), Hariya and Kennedy (1968), Boettcher (1970), and Huckenholz et al. (1975)

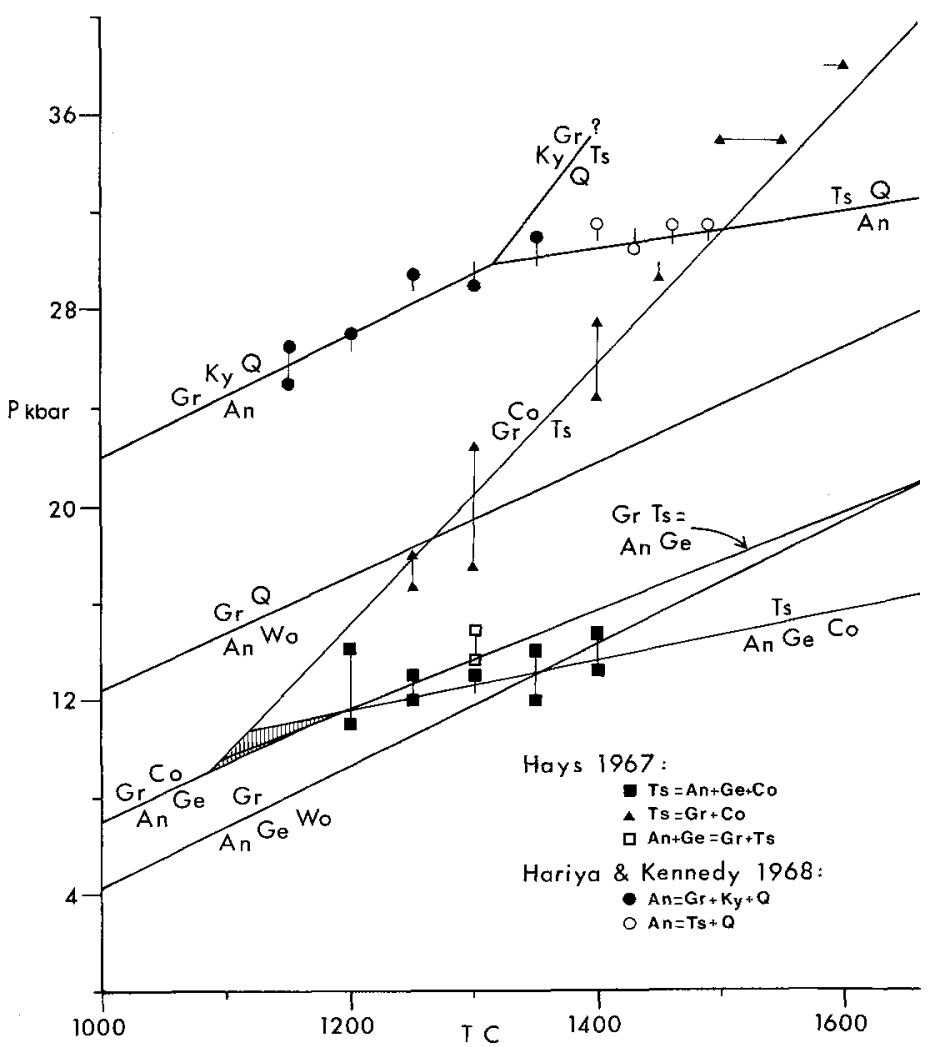

Fig. 3. Pressure-temperature diagram comparing the thermodynamic extrapolations of this study with experimental results of Hays (1967) and Hariya and Kennedy (1968). The stippled area indicates the area in which reactions $(3),(10),(11)$ and (12) intersect 
the curve is not consistent with the reversals of Huckenholz et al.; this could be due to some sort of systematic error in their low-pressure experiments.

(5) 3 anorthite $=$ grossular +2 kyanite + quartz

$$
3 \mathrm{CaAl}_{2} \mathrm{Si}_{2} \mathrm{O}_{8}=\mathrm{Ca}_{3} \mathrm{Al}_{2} \mathrm{Si}_{3} \mathrm{O}_{12}+2 \mathrm{Al}_{2} \mathrm{SiO}_{5}+\mathrm{SiO}_{2}
$$

The breakdown of anorthite (reaction 5) has been considered by Hays (1967), Newton (1966) and Hariya and Kennedy (1968). A curve consistent with Hariya and Kennedy's reversal at 26 to $28.5 \mathrm{kbar}$ has been determined and plots within all reversals (Fig. 2 and 3).

(6) grossular + quartz $=$ anorthite +2 wollastonite

$$
\mathrm{Ca}_{3} \mathrm{Al}_{2} \mathrm{Si}_{3} \mathrm{O}_{12}+\mathrm{SiO}_{2}=\mathrm{CaAl}_{2} \mathrm{Si}_{2} \mathrm{O}_{8}+2 \mathrm{CaSiO}_{3}
$$

This reaction has been determined by Hays (1967), Newton (1966), Boettcher (1970) and Huckenholz et al. (1975). A thermodynamic extrapolation from Newton's $750^{\circ} \mathrm{C}$ reversal is consistent with all reversals except those of Huckenholz et al. at low pressure (Fig. 2). The discrepancy between the results of Huckenholz et al. and earlier workers is small but systematic.

(7) 4 lawsonite $=2$ zoisite + kyanite + quartz +7 water

$$
4 \mathrm{CaAl}_{2}(\mathrm{OH})_{2} \mathrm{Si}_{2} \mathrm{O}_{7} \mathrm{H}_{2} \mathrm{O}=2 \mathrm{Ca}_{2} \mathrm{Al}_{3} \mathrm{Si}_{3} \mathrm{O}_{12}(\mathrm{OH})+\mathrm{Al}_{2} \mathrm{SiO}_{5}+\mathrm{SiO}_{2}+7 \mathrm{H}_{2} \mathrm{O}
$$

This reaction was experimentally located by Newton and Kennedy (1963). In order to perform thermodynamic calculations, it was necessary to have the entropy of lawsonite. $S_{298}$ was taken from Robie and Waldbaum (1968); several different schemes for $\mathrm{S}_{\mathrm{T}}-\mathrm{S}_{298}$ were attempted. Results most consistent with reactions (7) and (8) (Table 4 ) were obtained by the approximation:

$$
\begin{aligned}
\left(\mathrm{S}_{\mathrm{T}}-\mathrm{S}_{298}\right)_{1 \mathrm{w}}= & 2\left(\mathrm{~S}_{\mathrm{T}}-\mathrm{S}_{298}\right)_{\mathrm{tc}}+\left(\mathrm{S}_{\mathrm{T}}-\mathrm{S}_{298}\right)_{\mathrm{di}}+\left(\mathrm{S}_{\mathrm{T}}-\mathrm{S}_{298}\right)_{\mathrm{ky}} \\
& -7\left(\mathrm{~S}_{\mathrm{T}}-\mathrm{S}_{298}\right)_{\mathrm{en}}+-2\left(\mathrm{~S}_{\mathrm{T}}-\mathrm{S}_{298}\right)_{\mathrm{q}}
\end{aligned}
$$

where $1 \mathrm{w}=$ lawsonite, $\mathrm{tc}=$ talc, $\mathrm{di}=$ diopside, $\mathrm{ky}=\mathrm{kyanite}, \mathrm{en}=$ enstatite, and $\mathrm{q}=$ quartz.

Extrapolation from Newton and Kennedy's $16 \mathrm{kbar}$ reversal is shown in Figure 2 along with the most limiting of their piston-cylinder reversals and half reversals. The agreement between our theoretical curve and the high pressures results of Newton and Kennedy is excellent.

Table 4. Estimated Entropy of Lawsonite

\begin{tabular}{llll}
\hline$\frac{\mathrm{T}}{\mathrm{K}}$ & $\begin{array}{l}\mathrm{S}^{0} \\
\left(\mathrm{cal} \mathrm{mol}^{-1} \mathrm{~K}^{-1}\right)\end{array}$ & $\frac{\mathrm{T}}{\mathrm{K}}$ & $\begin{array}{l}\mathrm{S}^{0} \\
\left(\mathrm{cal} \mathrm{mol}^{-1} \mathrm{~K}^{-1}\right)\end{array}$ \\
\hline 298.15 & 55.88 & 650 & 124.03 \\
300 & 56.19 & 700 & 131.79 \\
350 & 65.90 & 750 & 139.03 \\
400 & 76.51 & 800 & 145.77 \\
450 & 87.08 & 850 & 152.06 \\
500 & 97.20 & 900 & 157.93 \\
550 & 106.76 & 950 & 163.43 \\
600 & 115.69 & 1000 & 168.57 \\
\hline
\end{tabular}


(8) 2 zoisite + sillimanite + quartz $=4$ anorthite + water

$$
2 \mathrm{Ca}_{2} \mathrm{Al}_{3} \mathrm{Si}_{3} \mathrm{O}_{12}(\mathrm{OH})+\mathrm{Al}_{2} \mathrm{SiO}_{5}+\mathrm{SiO}_{2}=4 \mathrm{CaAl}_{2} \mathrm{Si}_{2} \mathrm{O}_{8}+\mathrm{H}_{2} \mathrm{O}
$$

Reaction (8) was experimentally located by Newton and Kennedy (1963), and Newton (1966). Newton (1966) noted that it is metastable with respect to the reaction:

2 zoisite + kyanite + quartz $=4$ anorthite + water

Thermodynamic calculations show that it shifts by $5^{\circ} \mathrm{C}$ to $10^{\circ} \mathrm{C}$ downwards when corrected for kyanite. An extrapolation of this reaction from Newton's $550^{\circ} \mathrm{C}$ reversal is shown in Figure 2.

(9) lawsonite $=$ anorthite +2 water

$$
\mathrm{CaAl}_{2}(\mathrm{OH})_{2}\left(\mathrm{Si}_{2} \mathrm{O}_{7}\right) \mathrm{H}_{2} \mathrm{O}=\mathrm{CaAl}_{2} \mathrm{Si}_{2} \mathrm{O}_{8}+2 \mathrm{H}_{2} \mathrm{O}
$$

Reaction (9), Figure 2, was experimentally located at 5 to $8 \mathrm{kbar}$ by Crawford and Fyfe (1965). As pointed out by Newton and Kennedy (1963), it can only be stable on the low pressure, low temperature side of an invariant point where reactions (7), (8), and (9) intersect since lawsonite is metastable with respect to $\mathrm{zo}, \mathrm{ky}, \mathrm{q}$ and $\mathrm{V}$ on the high temperature side of reaction (7). Thermodynamic extrapolations of reactions (7), (8), and (9) indicate that no such invariant point exists in real $P-T$ space, although the reactions do pass within $30^{\circ} \mathrm{C}$ of each other at 1 atmosphere pressure.

(10) $3 \mathrm{CaTs}=$ anorthite + gehlenite + corundum

$$
3 \mathrm{CaAl}_{2} \mathrm{SiO}_{6}=\mathrm{CaAl}_{2} \mathrm{Si}_{2} \mathrm{O}_{8}+\mathrm{Ca}_{2} \mathrm{Al}_{2} \mathrm{SiO}_{7}+\mathrm{Al}_{2} \mathrm{O}_{3}
$$

Reaction (10) was experimentally located by Hays (1967). In order to perform thermodynamic calculations on this reaction, it was necessary to estimate the entropy of CaTs. We attempted several different schemes involving the entropies of diopside, gehlenite, and akermanite, but found our estimates to be significantly low (even when we adjusted our values for disordered Si and Al). For our final calculations, we used the entropy values of Hays (in Robie and Waldbaum, 1967). Since Hays' values were derived from his experiments, a thermodynamic extrapolation (Fig. 3) is consistent with all reversals for reaction (10).

(11) $3 \mathrm{CaTs}=$ grossular +2 corundum

$$
3 \mathrm{CaAl}_{2} \mathrm{SiO}_{6}=\mathrm{Ca}_{3} \mathrm{Al}_{2} \mathrm{Si}_{3} \mathrm{O}_{12}+\mathrm{Al}_{2} \mathrm{O}_{3}
$$

The breakdown of CaTs to grossular and corundum has been reversed by Hays (1967) over a pressure range of 15 to $40 \mathrm{kbar}$. It must pass through the invariant point at which reactions (3), (10), and (12) intersect. Thermodynamic extrapolation, consistent with Hays' $1250^{\circ} \mathrm{C}$ reversal, fits all reversals except those at 30 to $40 \mathrm{kbar}$, and passes near to the intersection of reactions (3) and (10) (Fig. 3). The small discrepancies at elevated pressures may be the result of minor errors in Hays' estimated CaTs entropy, or they may be manifestations of inaccuracies in the pressures calibration of Hays' piston cylinder device. 
(12) anorthite +2 gehlenite $=$ grossular $+3 \mathrm{CaTs}$

$$
\therefore \mathrm{CaAl}_{2} \mathrm{Si}_{2} \mathrm{O}_{8}+2 \mathrm{Ca}_{2} \mathrm{Al}_{2} \mathrm{SiO}_{7}=\mathrm{Ca}_{3} \mathrm{Al}_{2} \mathrm{Si}_{3} \mathrm{O}_{12}+\mathrm{CaAl}_{2} \mathrm{SiO}_{6}
$$

Hays (1967) demonstrated one reversal for reaction (12). Extrapolation from this reversal (Fig. 3) is consistent with the invariant point at which reactions (3), (10) and (11) intersect.

(13) anorthite $=\mathrm{CaTs}+$ quartz

$$
\mathrm{CaAl}_{2} \mathrm{Si}_{2} \mathrm{O}_{8}=\mathrm{CaAl}_{2} \mathrm{SiO}_{6}+\mathrm{SiO}_{2}
$$

This reaction was experimentally located by Hariya and Kennedy (1968), as shown in Figure 3. They only demonstrated that anorthite could be grown from CaTs plus quartz at one pressure and temperature. In view of the limited data, and possible metastability with respect to reaction (11), more experiments are needed to locate this reaction definitively.

(14) $3 \mathrm{CaTs}+2$ quartz $=$ grossular +2 kyanite

$$
3 \mathrm{CaAl}_{2} \mathrm{SiO}_{6}+2 \mathrm{SiO}_{2}=\mathrm{Ca}_{3} \mathrm{Al}_{2} \mathrm{Si}_{3} \mathrm{O}_{12}+2 \mathrm{Al}_{2} \mathrm{SiO}_{5}
$$

(15) 3 anorthite $=2$ corundum + grossular +3 quartz

$$
3 \mathrm{CaAl}_{2} \mathrm{Si}_{2} \mathrm{O}_{8}=2 \mathrm{Al}_{2} \mathrm{O}_{3}+\mathrm{Ca}_{3} \mathrm{Al}_{2} \mathrm{Si}_{3} \mathrm{O}_{12}+3 \mathrm{SiO}_{2}
$$

Reactions (14) and (15) emanate from invariant points at which reaction (13) intersects reactions (5) and (11) respectively. Neither reaction has been reversed, although Hariya and Kennedy (1968) have limited the location of reaction (14) by growing CaTs plus quartz from grossular plus kyanite at $34 \mathrm{kbar}$ and $1445^{\circ} \mathrm{C}$. The shallow angle of intersection between reaction (13) and reactions (14) and (15) results in large uncertainties in the location of the invariant points. More experimentation is needed to pin down these reactions.

The excellent agreement between the experiments and our calculated curves for ten reactions confirms the accuracy of our measured grossular entropies. Four reactions involving zoisite yield good agreement between experiment and theory, indicating that our estimated zoisite entropies are also reliable. The lawsonite values were only checked against two reactions; nonetheless we believe them to be reliable because of their fit to the tight reversals of reaction (7). The existence of reliable entropy values for these three phases allows many thermodynamic calculations to be made that were previously unreliable.

\section{Entropies of Other Garnets}

To estimate the entropies of pyrope and andradite we used a summation method involving the entropy of grossular and that of other phases from Robie and Waldbaum (1968):

$$
\mathrm{S}_{\text {pyrope }}=\mathrm{S}_{\text {grossular }}+3 / 2\left(\mathrm{~S}_{\text {forsterite }}-\mathrm{S}_{\text {Ca-olivine }}\right)
$$


For the estimation of andradite entropy was used:

$\mathrm{S}_{\text {andradite }}=\mathrm{S}_{\text {grossular }}+\mathrm{S}_{\mathrm{Fe}_{2} \mathrm{O}_{3}}-\mathrm{S}_{\mathrm{Al}_{2} \mathrm{O}_{3}}$

A volume correction term (Fyfe et al., 1958) was not applied because the term is negligible.

To check our estimates we calculated the entropy of pyrope at $1000^{\circ} \mathrm{C}$ based upon the experimentally determined curve:

forsterite + Al-enstatite + spinel $=$ forsterite + Al-poor enstatite + pyrope

reversed by MacGregor $(1964,1974)$. We used the Al content of the enstatite as given by MacGregor and adjusted its entropy assuming ordered tschermakenstatite pyroxene (after Ganguly and Ghose, 1975). Our estimated and slope determined entropies (Table 5) show large disagreement.

We also calculated the entropy of pyrope based upon the slope of the reaction:

pyrope + quartz $=$ Al-enstatite + sillimanite

as studied by Hensen and Essene (1971) and found our estimated entropy to be at least $13 \mathrm{cal} \mathrm{K}^{-1} \mathrm{~mol}^{-1}$ too low (Table 5).

To determine the validity of our estimated andradite entropies we made similar slope calculations on the reaction:

andradite $=$ wollasonite + hematite

as determined by Huckenholz and Yoder $(1971 \mathrm{a}, \mathrm{b})$. We found that the slopedetermined entropy of andradite was significantly greater than our estimate at $1200^{\circ} \mathrm{C}$, representing an error of $14 \%$ (Table 5).

Table 5. Estimated and Calculated Entropies of Pyrope and Andradite ( $\mathrm{cal} \mathrm{mol}^{-1} \mathrm{deg}^{-1}$ )

\begin{tabular}{lll}
\hline & Calculated & Estimated \\
\hline $\mathrm{S}_{\mathrm{py}}\left(727^{\circ} \mathrm{C}\right)$ & $187.1^{\mathrm{a}}$ & 171.1 \\
$\mathrm{~S}_{\mathrm{py}}\left(727^{\circ} \mathrm{C}\right)$ & $188.3^{\mathrm{b}}$ & 171.1 \\
$\mathrm{~S}_{\mathrm{an}}\left(1200^{\circ} \mathrm{C}\right)$ & $294.6^{\mathrm{c}}$ & 269.0 \\
\hline
\end{tabular}

a From experiments by MacGregor (1974)

${ }^{b}$ From experiments by Hensen and Essene (1971)

c From experiments by Huckenholz and Yoder (1971 a, b)

It is not clear why such discrepancies exist between the experiments and our estimated garnet entropies although presumably our estimates are in error. Although the $\mathrm{Ca}$ in grossular is in 8 -fold coordination while the $\mathrm{Ca}$ in Ca-olivine is in 6-fold coordination, similar calculations lead to differences of less than $1 \mathrm{cal} \mathrm{K}-1 \mathrm{~mol}^{-1}$ per atom for other elements and other minerals. Resolution of the large discrepancies may not be achieved until heat capacities are measured for other garnets besides grossular.

Acknowledgments. This paper was supported by the Geological Society of America, The Scott Turner Awards in Earth Science (University of Michigan), and by N.S.F. grant GP-42525X to E.F. Westrum, Jr. In addition, the authors are very grateful to Dr. Richard A. Robie and Dr. Bruce E. Hemingway for allowing DSC measurements to be made in their lab at the U.S.G.S., and to Dr. Robert C. Newton for his advice and criticism. 


\section{References}

Boettcher, A.L.: The system CaO-Al ${ }_{2} \mathrm{O}_{3}-\mathrm{SiO}_{2}-\mathrm{H}_{2} \mathrm{O}$ at high pressures and temperatures. J. Petrol. 11, $337-79(1970)$

Clark, S.P., Jr.: Handbook of Physical Constants. Geol. Soc. Am. Mem. 97, 1966

Crawford, W.A., Fyfe, W.S.: Lawsonite equilibria. Am. J. Sci. 263, 262-270 (1965)

Ditmars, D.A., Douglas, T.B.: Measurement of the relative enthalpy of pure $\mathrm{Al}_{2} \mathrm{O}_{3}$ (NBS Heat capacity and enthalpy standard reference material No. 270 ) from 273 to $1173 \mathrm{~K}$. U.S. National Bureau of Standards J. Research 75 A, 401-420 (1971)

Fyfe, W.S., Turner, F.J., Verhoogen, J.: Metamorphic Reactions and Metamorphic Facies. Geol. Soc. Am. $73(1958)$

Ganguly, J., Ghose, S.: Intracrystalline cation distribution in aluminous orthopyroxene and its implications. International Geobarometry-Geothermometry Conference, Penn. State Univ. (1975)

Hariya, Y., Kennedy, G.C.: Equilibrium study of anorthite under high pressure and high temperature. Am. J. Sci. 266, 193-203 (1968)

Hays, J. F.: Lime-alumina-silica. Carnegie Inst. Wash. Yearbook 65, 234-49 (1967)

Hensen, B.J., Essene, E. J.: Stability of pyrope +quartz in the system $\mathrm{MgO}-\mathrm{Al}_{2} \mathrm{O}_{3}-\mathrm{H}_{2} \mathrm{O}$. Contrib. Mineral. Petrol. 83, 72-83 (1971)

Huckenholz, H.G., Holz, E., Lindhuber, W.: Grossularite, its solidus and liquidus relations in the $\mathrm{CaO}-\mathrm{Al}_{2} \mathrm{O}_{3}-\mathrm{SiO}_{2}-\mathrm{H}_{2} \mathrm{O}$ system up to $10 \mathrm{~kb}$. Neues Jahrb. Mineral. Abhandl. 124, 1-46 (1975)

Huckenholz, H.G., Yoder, H.S., Jr.: Andradite stability in air at $1 \mathrm{~atm}, \mathrm{O}_{2}$ up to $30 \mathrm{~kb}$, and $\mathrm{H}_{2} \mathrm{O}+\mathrm{O}_{2}$ up to $20 \mathrm{~kb}$ total pressure. Carnegie Inst. Wash. Yearbook 69, $182(1971 \mathrm{a})$

Huckenholz, H.G., Yoder, H.S., Jr.: Andradite stability in the $\mathrm{CaSiO}_{3}-\mathrm{Fe}_{2} \mathrm{O}_{3}$ join up to $30 \mathrm{~kb}$. Neues Jahrb. Mineral. Abhandl. 114, 246-80 (1971 b)

Kiseleva, I.A., Topor, N.D., Andreyenko, E.D.: Thermodynamic properties of minerals of the epidote group. Geochem. Internat. 289-98 (1974)

Krupka, K.: DSC-7 c, A computer program for refining DSC data. Personal communication (1976)

Louisnathan, S.J.: Refinement of the crystal structure of a natural gehlenite, $\mathrm{Ca}_{2} \mathrm{Al}(\mathrm{Al}, \mathrm{Si})_{2} \mathrm{O}_{7}$. Can. Mineralogist 10, 822-37 (1971)

MacGregor, I.D.: The reaction 4 enstatite + spinel $\rightleftarrows$ forsterite + pyrope. Carnegie Inst. Wash. Yearbook 63, 157 (1964)

MacGregor, I.D.: The system $\mathrm{MgO}-\mathrm{Al}_{2} \mathrm{O}_{3}-\mathrm{SiO}_{2}$ : solubility of $\mathrm{Al}_{2} \mathrm{O}_{3}$ in enstatite for spinel and garnet peridotite compositions. Am. Mineralogist 59, 110-19 (1974)

Merrin, S.: Experimental investigation of epidote paragenesis. Diss. Penn. St. Univ. (1962)

Newton, R.C.: The thermal stability of zoisite. J. Geol. 73, 431-41 (1965)

Newton, R.C.: Some calc-silicate equilibrium relations. Am. J. Sci. 264, 204-22 (1966)

Newton, R.C., Charlu, T.V., Kleppa, O.J.: Heat of solution of grossular-pyrope garnets. Personal communication (1975)

Newton, R.C., Kennedy, G. C.: Some equilibrium reactions in the join $\mathrm{CaAl}_{2} \mathrm{Si}_{2} \mathrm{O}_{8}-\mathrm{H}_{2} \mathrm{O}$. J. Geophys, 68, 2967-83 (1963)

Nitsch, K.H., Winkler, H.G.F.: Bildungsbedingungen von Epidot und Orthozoisit. Beit. Mineral. Petrol. 11, 470-86 (1965)

Robie, R.A., Bethke, P.M., Beardsley, K.M.: Selected X-ray crystallographic data. U.S. Geol. Surv. Bull. 1259 (1967)

Robie, R.A., Waldbaum, D.R.: Thermodynamic properties of minerals and related substances at $298.15 \mathrm{~K}\left(25^{\circ}\right)$ and one atmosphere (1.013 bars) and at higher temperatures. U.S. Geol. Surv. Bull. 1259 (1968)

Smith, J.V.: Reexamination of the crystal structure of melilites. Am. Mineralogist 38, 643 (1953)

Thompson, A.B.: Gibbs energy of aluminous minerals. Contrib. Mineral. Petrol. 48, 123-36 (1974)

Waldbaum, D.A.: The configurational entropies of $\mathrm{Ca}_{2} \mathrm{MgSi}_{2} \mathrm{O}_{7}-\mathrm{Ca}_{2} \mathrm{SiAl}_{2} \mathrm{O}_{7}$ melilites and related minerals. Contrib. Mineral. Petrol. 39, 33-54 (1973)

Westrum, E. F., Jr., Essene, E.J., Perkins, D., III: Thermophysical properties of the garnet, grossularite $\left(\mathrm{Ca}_{3} \mathrm{Al}_{2} \mathrm{Si}_{3} \mathrm{O}_{12}\right)$. Submitted for publication to $\mathrm{J}$. Chem. Thermodyn. (1977) 